\title{
sciendo
}

DOI 10.2478/sbe-2020-0018

SBE no. 15(1) 2020

\section{ROLE OF CORPORATE GOVERNANCE IN BANK'S EFFICIENCY IN PAKISTAN}

\author{
SAIF ULLAH \\ SZABIST Karachi, Pakistan
}

\begin{abstract}
:
The purpose of this research paper is to explore the role of corporate governance of banks (independence of the board, board size, CEO duality, audit committee independence, managerial ownership) to boosting up the bank's efficiency. The study uses bank size, macro-economic conditions, banking structure and economic freedom as control variables. The sample size of the study is 21 Pakistani banks for the period of 2007-2016 and fixed effect panel regression estimation technique is used for data analysis. The results suggest that corporate governance has a statistically significant negative impact on management efficiency, positive effect on profit efficiency and cost efficiency of the banks. Moreover, the findings show that operating efficiency turned out to have a statistically insignificant relationship with corporate governance. Reforms of corporate governance should be adopted efficiently and effectively to boost the banking sector efficiency.
\end{abstract}

Key words: Bank's Efficiency, Corporate Governance, Cost Efficiency, Management Efficiency

\section{Introduction}

International corporate scandals like WorldCom's and Enron's provide quick and vigorous attention to corporate governance. Better corporate governance shows that the business environment is transparent while weak corporate governance indicates mismanagement and corruption. The corporate governance of banks differs from the corporate governance of other business entities, because of depositor's exposure in addition to shareholders, and higher government involvement in the financial system (Fanta, Kemal \& Wake, 2013).In developing countries, better corporate governance, especially in the bank's sector, is needed as the banks are the primary source of savings. The banking sector has a vital role in the development of the economy across the globe and failure may threaten the whole economy of a country (Shari, Khalique \& Isa, 2010). Healthier corporate governance of banks can encourage banking efficiency to make the investments and improve the business environment to boost not only the shareholder's wealth but also for the better retune to depositors, the general public and other stakeholders.

In developing countries, banks efficiency gain massive attention from the last three decades. According to Hayat (2011), the maximum use of already given resources in a 
more productive and improved way refers to efficiency. Mirzaei and Moore, (2019) revealed from empirical evidence that efficient banking sectors might help in faster growth of countries with dependence on external finance. The efficient banking sector also assists in creating unconcentrated industrial sectors. However, they pointed out that many studies in banks efficiency are using single or some quantitative measures while there is a need to use qualitative measures of banking efficiency. Partovi and Matousek (2019) claimed that the level of banking efficiency depends on the ownership structure in Turkish banks. Novickyte and Droždz, (2018) contended that banks play an essential role in the financial system and contribute inefficient resource allocation and promotion of economic growth.

Recently, in Pakistan case of KASB bank arises an essential question of why taxpayers and depositors should bear the cost of banks poor governance. The issue of the bank's efficiency is highlighted due to privatization and opening-up the emerging countries in the deregulation and financial reforms. Historically, the reforms of 1993-1995 in banking sector increase the performance of foreign banks, NCBs, partly private banks, and private domestic banks. However, during 1995-1997 and onward private domestic bank's market share based on deposit and growth increase in Pakistan.

The concept of corporate governance of banks in Pakistan is not very old. In Pakistan, the first corporate governance code was introduced in 2002 by the SECP. The code was the first step in the system to implement sound corporate governance principles and procedures. The first codes have no proper instructions on risk management, internal control, compensation policies and limited provisions on the director's independence (Javed \& Iqbal, 2010). However, the code of corporate governance in 2002 improves overall governance structure and process in the decision making of the firms in Pakistan. SECP revised the code of corporate governance in April 2012 for transparency, better governance and to protect the investor's interests by financial reporting of the company improvement. On November 22, 2017, again a revised code of corporate governance issued by SECP for better corporate governance environment. The code revised the shortfall and introduced the new strict rules and regulations.

This introduction of the code of corporate governance 2017 suggests a comprehensive study of corporate governance compliance (codes of corporate governance 2002 \& 2012) and its role in the bank's efficiency. The main problem is in Pakistan research on corporate governance issue mostly focus on non-financial firms. The majority of studies including Rehman and Mangla, (2010) and Javed and Iqbal, (2010) excluded banks from their sample. This is because banks have a different capital requirement, nature of business and stakeholders. This created an opportunity to study corporate governance of banks during different code of corporate governance and their role in the bank's efficiency. The concept of corporate governance and its role in the efficiency of banks got attention after incorporating reforms and global banking sector panics. Moreover, in Pakistan after the recent development of corporate governance code 2017 policies, rules and regulations; it is essential to evaluate compliance of previous 2002 and 2012 codes of corporate governance and their role in bank's efficiency.

Abreu, Kimura, and Sobreiro (2019) examined 87 research papers from 2011 to 2017 published on banking efficiency and found low research productivity in the field of banking efficiency. They further suggested that banking efficacy should not only study due 
to the financial crisis but also due to the introduction of new technologies, regulatory changes and structural changes in the banking sector. In Pakistan, the banking sector efficiency is not fully explored in the recent financial environment. In the case of Pakistan, the literature on the relationship between corporate governance and bank's efficiency subject is scarce in the context of regulatory changes and to add to the empirical research. The aim of the study is to empirically assesses the role of corporate governance (Corporate governance score calculated using board size, managerial ownership, the duality of the CEO, board independence, and the independence of the audit committee) on bank's efficiency dimension's like profit efficiency, cost efficiency, management and operating efficiency while controlling macroeconomic condition, bank size, banking structure and economic freedom. This study considers that the efficiency of banks can attract domestic and foreign investment in shaping up the banking sector and economic growth in the country.

This study further follows as the review of the literature, the variable's relationship, research methodology, estimation techniques, model results, and conclusion.

\section{Literature Review}

\subsection{Corporate governance concept}

Corporate governance concept emerged in the 1990s due to the corporate scandal in developed countries. La Porte, Heifer and Vishnu (1999) defined corporate governance as a collection of tools by which external investors protected from expropriation caused by insiders. Deb (2013) defined corporate governance as "the tool through which firms are directed and controlled." In the banking industry, corporate governance includes a method in which the matter is regulated by the top management and board of directors and participates in corporate goals of banks. In simple words, corporate governance is defined as an activity that involves generating economic returns for owners, caring for shareholders' interests, conducting day to day business operations, supporting corporate social responsibilities, proving a secure way to adequately address the relevant laws and regulations while saving the interests of depositors and other stakeholders (Basel, 1999).

Internal control refers to the governing control and the rules of the operating structure of the banks. The operating structure rules include internal inception process, compliance control, risk, and financial reporting management. Moreover, focus on control objectives; proper on time information sharing and productive communication; control environment; regular identification and evaluation of risks; monitoring and taking corrective action of procedures can lead to a board of directors effective internal financial control. A firm with internal managerial control can achieve its short-term objectives and can attain long-term targets, reliable managerial and financial reporting.

\subsection{Bank's Efficiency Concept}

According to Hayat (2011), the maximum use of already given resources in a more productive and improved way refers to efficiency. Banks efficiency plays a vital role in 
financial development and efficiency becoming increasingly important (Burki\& Ahmed, 2011). According to the Qayyum and Khan, (2007) banking sector continues to function under the diseconomies of scale; though in the reduction of banks cost, governance reforms and technology play a significant role at different levels of efficiency ranging from $87 \%$ to $49 \%$. In Pakistan, The outcome of domestic is less efficient as compared to foreign banks from 2000 to 2005. Waheed and Younus (2010) claimed that banks play an essential role in the financial system and contribute inefficient resource allocation and promotion of economic growth.

\section{Management Efficiency}

As per Pulic, (2000) value creation through intellectual capital through valueadded management and limited available resources and intellectual capital refers to management efficiency. While, Kujansivu and Lonnqvist, (2006) claimed that management efficiency could be described through earning per share, the expense to assets ratio and growth of assets within a company. The intellectual capital will remain with the firm when individuals leave the organization (Muhammad \& Ismail, 2009). Bharati (2010) used financial variables like EPS to measure efficiency for effective of bank management. Management efficiency usually does not show a real picture and found that management efficiency in the Pakistani banking sector is more in foreign banks than private banks.

\section{Cost Efficiency}

It is based on best practices that the cost that produces the same output in the same conditions. A bank is cost efficient if at the lowest cost it utilized given input and produce output at maximum level in short time duration under the same conditions. The banking sector inefficiency enhanced due to non-performing loans. The banks are overutilized due to diseconomies of scale. As per Burki and Niazi, (2010) banks owned by private and foreign investment are cost-efficient as compared to state-owned banks, while in comparison of all banks.

\section{Profit Efficiency}

Patti and Hardy, (2005) reported the results that foreign banks are more efficient regarding profit than others. Hayat, (2011) claimed that efficiency significant and privatized banks are more efficient than small and govt. Banks. Moreover, it concluded that improvement in the value of the firm and efficient line with corporate governance. The performance of privatized banks increases exceptionally well after financial reforms. On a broader context, it can be assumed that profit efficiency decreased due to government interventions.

\section{Operating Efficiency}

The cost of banks reduced significantly due to technology and governance reform, but the banking sector still has diseconomies of scale. Akhter (2010) reported that the operating efficiency of the average bank level as compared to foreign banks level is low in the domestic banks. Also, Qayyum and khan (2007) results are in line with Akhter, (2010) for comparison of national and foreign banks. Similarly, Levin (2004) claimed that 
funds effective distribution and mobilization reduces the capital cost of banks, increase capital development and productivity.

\subsection{Corporate Governance and Bank's Efficiency}

A look of the empirical literature shows that various components of corporate governance like managerial ownership, board independence, the CEO duality, board size, independence of audit committee and many more have directly and indirectly influenced the bank's profit, cost efficiency, management efficiency, and operating efficiency. According to Nazir and Alam (2011), efficient internal control leads to an increase in the performance of banks.

\section{Board Independence and Bank's efficiency}

Pathan (2009) studied the relationship between board independence of bank and efficiency in the USA showed that independent directors have negatively affected efficiency. Likewise, Klein (2002) found an antagonistic relationship between board independence and managing income. On the contrary, Eilon (1980) reported that an independent board of directors improves bank efficiency because they can make fair judgments and management. Recently, Bebchuk and Weisbach (2010) also proposed that the independent directors on the board are positively and directly related to better decision making. Andres and Vallelado (2008) estimated the panel regression model by using data from 620 banks of the UK, US, Italy, France, and Canada and found that the bank board meeting plays a more proactive role in the determination of bank performance.

\section{Board Size and Bank's Efficiency}

In every bank, the board of directors is the supreme body and responsible for overall management, plans, operations and return. For better corporate governance and profitability the board of directors should be strong regarding decision making and have a required experienced to perform their duties effectively and independently. As per international practices usually, a board size comprises of four members, while managerial (controlling) board have fourteen members. Forbes and Milliken (1999) claimed that in determining the efficiency of the board, overall board size, attendance, and proficiency play a vital part. Adams and Mehran (2005) argued that an active moderate bank board comprises sixteen directors which indicate three internal members and thirteen external members including nonexecutive directors. Vafeas (2005) explained that the large size of the board reduces the effectiveness of the business and lead to poor performance in term of profit. Minton, Taillard, and Williamson (2010) argued that the larger the board, the more free-riding behavior might happen. Hence, board size may affect a director's attendance and efficiency. Recently, Jegede, Akinlabi, and Soyebo (2013) asserted that board size should be small because in the practical world a more substantial board size results are less effective. Lipton and Lorsch (1992) argued that when a board size is too big, this refers to less effectiveness, challenging to manage, coordinate, and deal with strategic issues for the CEO. More recently, De Haan and Vlahu (2015) argued that banks with larger board size have weaker performance than firms with smaller boards. 


\section{CEO duality and Bank's Efficiency}

An ideal system of corporate governance means that there should not be the same person as the chairman and chief executive officer (CEO) of the board. $\mathrm{Pi}$ and Timme (1993) documented that if a bank has the same person as board chairman and chief executive officer (CEO), this leads to the cost efficiency of banks and profitability without such contrast. De Haan and Vlahu (2015) argued that if the person holds both positions, this indicates an increase in managerial power to affect board verdicts and it adversely influences the board monitoring activity. Pathan (2009) found that the feature of CEO power is argumentative through all bank procedures used and statistically significant in most gaps. According to the diversity perspective, Adams and Ferreira (2009) reported that the CEO is responsible for the lousy performance in case of a diverse board.

\section{Audit Committee Independence and Bank's Efficiency}

Audit committee does many tasks along with enabling auditor's independence in banks. Many bankruptcies and scandals were found due to weak internal control and making audit committee independence as essential determinants of bank's efficiency. Güneş and Atılgan (2016) compared the audit committee effectiveness of banks in Turkey and the UK and found a week association between audit committee independence and performance. Miko and Kamardin, (2016) found that audit committee independence positively and significantly related to the bank's efficiency in Nigeria.

\section{Managerial Ownership and Bank's Efficiency}

Managerial ownership has an impact on the profitability of banks. Wenyu (2016) claimed that management ownership is essential for non-transparent banks which made them difficult to monitor. Furthermore, Javid and Iqbal, (2010) and Njanike, Mutengezanwa and Gombarume, (2011) studies agree that distribution of ownership and bank structure plays a significant role in firm control to take healthier governance and monitoring practices which is stable with agency theory. According to MP theory, the escalated external market forces can lead to profit generation. The performance of the bank can be stimulated or dampened by both the internal and external factors. Tandelilin, Kaaro, Mahadwartha, and Supriyatna (2007) argued that dedicated shareholders have more power to control the firm than disperse shareholders which refer to better financial performance.

As per the viewpoint of bank ownership structure, countries have different shareholding ownership patterns with a combination of ownership arrangements, such as private ownership, public ownership and joint ownership (i.e., cooperative banks). The augmented version model found that the credit indicators would boost central bank's efficiency and private sector demands answers to more comfortable monetary conditions and may shift their credit origination toward riskier borrowers (Bakhit \& Bakhit, 2014). The bank formed of concentrated ownership studied by (Lassoued, Sassi \& Attia, 2016). Moreover, conclude that the banks owned by the government raise capital as funds for projects that bring the high return to politics and society. DeHaan and Vlahu, (2015) conceptualized this concept that if managers have larger equity stakes, they possibly act more similar principals and less like agents which leads to good corporate governance, profitability, management efficiency, efficiency control in operational day to day activities 
and cost of reduction. The state-owned banks are the example of large banks and have a high amount of assets (Zheng, Moudud, Rahmanc \& Ashraf, 2017).

\section{Theoretical Framework}

Internationally and in Pakistan previous studies more focus was on ownership structure, risk, and financial liberalization with efficiency and fewer on corporate governance. However, in the case of Pakistan there is still a need to explore the corporate governance role in banks efficiency, and after the recent development of corporate governance code 2017 policies, rules and regulations increase the urgency. So, this study focus is to determine the role of corporate governance in banks efficiency (management, cost, profit, and operating efficiency) in Pakistan by considering bank size, macroeconomic, banking structure and economic freedom as control variables. Moreover, consider subparts like board size, managerial ownership for internal control, the duality of the CEO/Chairman, board independence, and the independence of the audit committee on bank's efficiency aspect is like cost efficiency, profit efficiency, management efficiency, and operating efficiency. Furthermore, this study used macroeconomic condition, banking structure, and economic freedom variables as control variables. From above-cited literature, a theoretical framework can be developed for a better understanding of the phenomenon under study.

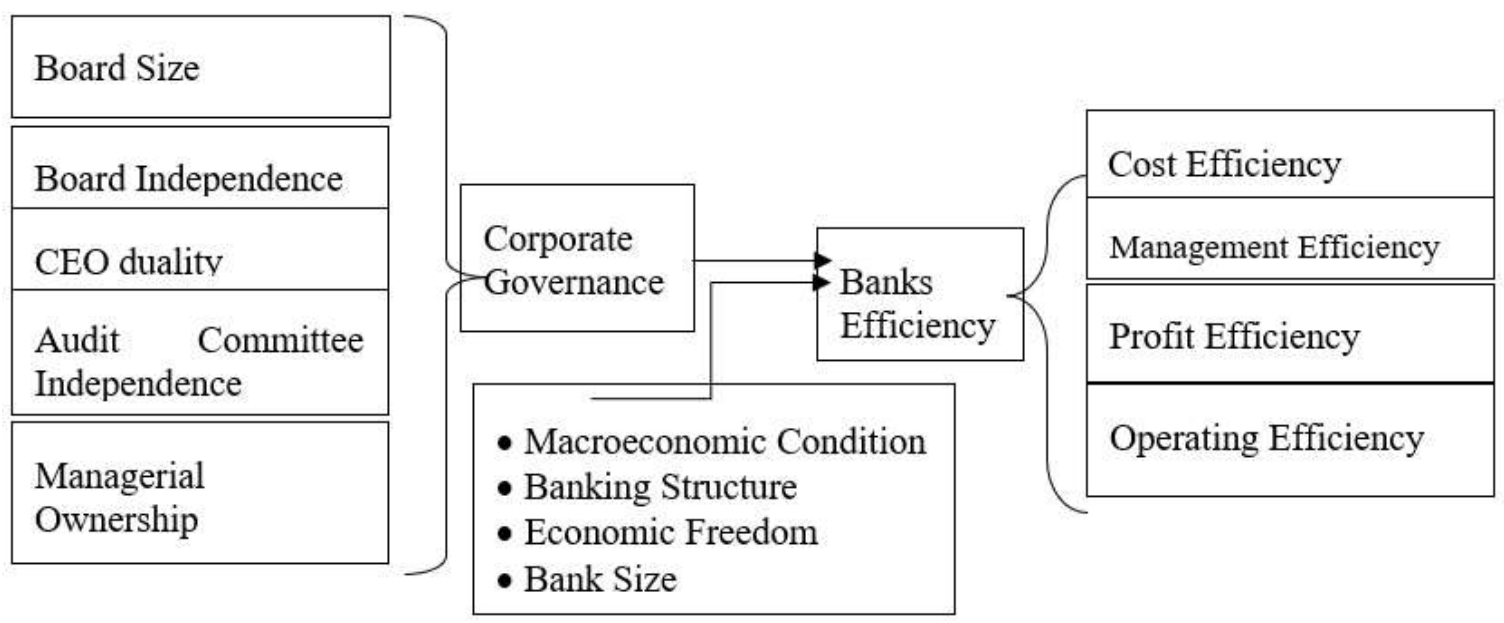

Figure 1: Theoretical Framework

Following research hypotheses are developed from the literature cited above and theoretical framework;

$H_{1}$ : Bank's corporate governance has a significant and positive effect on the Management efficiency of banks in Pakistan.

$\mathrm{H}_{2:}$ Bank's corporate governance has a significant and positive effect on the Cost efficiency of banks in Pakistan.

$H_{3}$ : Bank's corporate governance has a significant and positive effect on the Profit efficiency of banks in Pakistan. 
$H_{4}$ : Bank's corporate governance has a significant and positive effect on the Operating efficiency of banks in Pakistan.

\section{Research Methodology}

This study is an effort to determine the role of corporate governance in the bank's efficiency in Pakistan by considering macro-economic condition, banking structure, economic freedom, and bank size as controlling factors. In detail, this study empirically measures the impact of corporate governance as explanatory variables on the dependent variable bank's efficiency dimensions like cost efficiency, profit efficiency, management efficiency, and operating efficiency. This study takes five characteristics of corporate governance computed with dummy variables to test whether there is any impact of corporate governance on the efficiency of the bank.

There are 21 banks listed on Pakistan Stock Exchange (PSX) as on December 31, 2018. This study uses secondary data extracted from financial reports of 21 banks from Pakistan with a time horizon of the year 2007- 2016. Corporate governance longitudinal data of banks is collected and calculated from annual financial reports. Apart from the main variables in this study, the study takes four control variables such as bank size, macroeconomic conditions collected from World Bank, WDI and data of banking structure collected from the database of World Bank, Financial Structure and Development. Moreover, data for economic freedom is data collected through World Governance Indicators (WGI), World Bank.

Econometric model indicate that management efficiency (ME), profit efficiency $(P E)$, cost efficiency (CE), Operating efficiency (OE), Corporate Governance Index (CGI), Macroeconomic Conditions (MEC), Banking Structure (BS), economic freedom(EF), $\beta 0$ (intercept), e (error term).

An econometric model can be written as follow;

$M e_{i, t,}=\beta_{0}+\beta_{1}(C G I)_{i, t,}+\beta_{2}(\text { Size })_{i, t,}+\beta_{3}(M E C)_{i, t,}+\beta_{4}(B S)_{i, t,}+\beta_{5}(E F)_{i, t,}+\mu_{i, t, \ldots \ldots . . . .(I)}$

$P E_{i, t,}=\beta_{0}+\beta_{1}(C G I)_{i, t}+\beta_{2}(\text { Size })_{i, t,}+\beta_{3}(M E C)_{i, t,}+\beta_{4}(B S)_{i, t,}+\beta 5(E F)_{i, t,}+\mu_{i, t, \ldots \ldots \ldots . .(I I)}$

$C E_{i, t,}=\beta_{0}+\beta_{1}(C G I)_{i, t,}+\beta_{2}(\text { Size })_{i, t,}+\beta_{3}(M E C)_{i, t,}+\beta_{4}(B S)_{i, t,}+\beta 5$ (EF) $i, t,+\mu_{i, t,} \ldots \ldots \ldots$ (III)

$O E_{i, t,}=\beta_{0}+\beta_{1}(C G I)_{i, t,}+\beta_{2}$ (Size) $_{i, t,}+\beta_{3}(M E C)_{i, t,}+\beta_{4}(B S)_{i, t,}+\beta 5$ (EF) $)_{i, t,}+\mu_{i, t, \ldots \ldots} \ldots$ (IV)

The ongoing study is based on panel data and to estimate the impact of corporate governance of banks in efficiency in Pakistan by taking four control variables used panel regression technique. Before proceeding further, unit root tests for panel data conducted to test stationarity of data series used in study and before decision about estimation technique. The unit test Levin, Lin \& Chu test confirmed that all variables are stationary at level. Therefore, Panel regression estimation technique is used for data analysis using both random and fixed effect models. Further, Hausman test is conducted to know the model fitness of good as well to further know which estimation technique is more appropriate and then on the basis of Hausman test results applied the fixed effect model as estimation technique to estimate the final model.

The dimensions, calculations and measurement indicators used in this study for corporate governance index, bank's efficiency index and control variables are explained below. De 
Haan and Vlahu (2015) methodology measuring corporate governance are followed and for efficiency. Laeven, and Levine (2009) and Khrawish (2011). The corporate index is shown below in Table 1.

\section{Table 1: The Corporate Governance Index}

\begin{tabular}{|c|c|}
\hline Independent Variables & Indicators (Measurement) \\
\hline Board independence & $\begin{array}{l}\text { Board independence indicates the outside director's \% in a bank; Corporate } \\
\text { governance code } 2017 \text { recommend one-third member shall be independent } \\
\text { on board of each bank. Dummy variable }(1,0) \text { used to measure the board } \\
\text { independence by reporting one if } 67 \% \text { or more directors are independentno if } \\
\text { less than } 67 \% \text { of directors are independent. }\end{array}$ \\
\hline CEO Duality & $\begin{array}{l}\text { CEO duality indicates that if the CEO is also working as chairman of the bank. } \\
\text { Corporate governance code } 2017 \text { recommends that the CEO shall be } \\
\text { separate on the board. Dummy variable }(1,0) \text { used to measure the CEO } \\
\text { duality by reporting } 0 \text { if the CEO is also the chairperson of the board and one if } \\
\text { both are the same. }\end{array}$ \\
\hline Board size & $\begin{array}{l}\text { Board size indicates the total number of directors on the board of each bank } \\
\text { and Dummy variable }(1,0) \text { is used, to measure one if board members are less } \\
\text { than the median of the sample and } 0 \text { if greater than median of the sample. }\end{array}$ \\
\hline Managerial Ownership & $\begin{array}{l}\text { Managerial ownership for internal control indicate the percentage } \\
\text { Of shares held by Management (executive director and senior management) } \\
\text { divided by the total number of shares held in each bank. } \\
\text { Dummy variable }(1,0) \text { is used to measure one if the percentage is less than } \\
\text { the sample median and } 0 \text { if \%age is higher than the sample median. }\end{array}$ \\
\hline $\begin{array}{l}\text { Audit committee } \\
\text { independence }\end{array}$ & $\begin{array}{l}\text { Audit committee independence indicates that percentage of the independent } \\
\text { director include in committee of each bank and corporate governance code } \\
2017 \text { recommend that one-third of the board members shall be independent } \\
\text { including committee chairman. Dummy variable }(1,0) \text { is used to measure } \\
\text { Audit committee independence, one if total percentage is higher than one-third } \\
\text { of the board members and } 0 \text { if total percentage is less than one-third of the } \\
\text { audit committee size. }\end{array}$ \\
\hline
\end{tabular}

Table 2: The Banks Efficiency (Dependent Variables)

\begin{tabular}{ll}
\hline Efficiency Dimensions & Indicators (Measurement) \\
\hline Profit Efficiency & $\begin{array}{l}\text { EPS, We have taken earnings per share as one of the banks that is a proxy to } \\
\text { how efficient the management of the bank is as well as earning and market } \\
\text { share of the bank. } \\
\text { Expense to Asset ratio }\{\text { (Admin expense + Noninterest Expense/Total Assets)\} }\end{array}$ \\
$\begin{array}{ll}\text { Cost Efficiency } \\
\text { Management Efficiency }\end{array}$ & $\begin{array}{l}\text { Assets Ratio (Average total assets divided by Total revenue } \\
\text { Operating Efficiency }\end{array}$ \\
\hline
\end{tabular}

\begin{tabular}{|c|c|}
\hline Control variables & Indicators (Measurement) \\
\hline $\begin{array}{l}\text { Macro-economic } \\
\text { condition }\end{array}$ & $\begin{array}{l}\text { Macroeconomic conditions are measured through the real interest rate (Annual } \\
\% \text { change) }\end{array}$ \\
\hline Banking Structure & $\begin{array}{l}\text { Banking Structure is measured through bank concentration by taking the three } \\
\text { largest banks' assets/total banking sector assets. }\end{array}$ \\
\hline Economic Freedom & $\begin{array}{l}\text { Through control of corruption extent to which public power is exercised for } \\
\text { private gain, including both petty and grand forms of corruption, as well as } \\
\text { "capture" of the state by elites and private interests economic freedom is } \\
\text { measured. }\end{array}$ \\
\hline Bank Size & $\begin{array}{l}\text { Log of total assets of a bank, Bank size proxy used (Zhu \&Yang, 2016); } \\
\text { (Lassoued, Sassi and Attia, 2016). }\end{array}$ \\
\hline
\end{tabular}




\section{Results and Analysis}

Table 4 presents descriptive statistics results. The results show mean score value of corporate governance is 4.25 which includes (board independence, managerial ownership for internal control, the board of directors/ board size, CEO duality and independence of the audit committee) related to 21 banks of Pakistan. The results indicate that the mean value of profit efficiency (EPS) is 4.54; it means the average trend is earning per share in the banking industry of Pakistan is good. Mean value of management efficiency is 1.15 which show the work level, through resources. The mean value of cost efficiency is 1.84; it shows that the cost reduction minimizes the cost and maximization of the resources, the result shows the less bank insolvency average. Jarque-Bera test shows that data is normal and can be used for reliable results. The results of the descriptive statistics show below.

Table4: Descriptive Statistics

\begin{tabular}{llllll}
\hline & $\begin{array}{l}\text { Corporate } \\
\text { Governance }\end{array}$ & $\begin{array}{l}\text { Profit } \\
\text { Efficiency }\end{array}$ & $\begin{array}{l}\text { Operating } \\
\text { Efficiency }\end{array}$ & $\begin{array}{l}\text { Cost } \\
\text { Efficiency }\end{array}$ & $\begin{array}{c}\text { Management } \\
\text { Efficiency }\end{array}$ \\
\hline Mean & 4.25 & 4.54 & 0.04 & 1.84 & 1.15 \\
Jarque-Bera & 86.09 & 41.30 & 5105.03 & 23981.55 & 5191.13 \\
Probability & 0.00 & 0.00 & 0.00 & 0.00 & 0.00 \\
Observations & 248.00 & 248.00 & 248.00 & 248.00 & 248.00 \\
\hline
\end{tabular}

Table 5 shows the results of the relationship among corporate governance, management efficiency, cost efficiency, profit efficiency, and operating efficiency. The correlation matrix is used when the study contains multiple variables. Correlation of each variable with itself gives the value of 1 . The higher values indicate a higher correlation the lower value specifies a lower association. Table 5 shows that corporate governance is negatively correlated with management efficiency by $14.8 \%$. Corporate governance of banks is positively associated with profit efficiency, cost efficiency and operating efficiency by $19.3 \%, .04 \%$, and $10.7 \%$ respectively. The correlation matrix is not high, so there is no problem of multicollinearity.

Table 5: Results of Correlation Matrix

\begin{tabular}{llllll}
\hline Variables & CG & ME & EPS & CE & OE \\
\hline Corporate Governance (CG) & 1.000 & & & & \\
Management Efficiency (ME) & -0.148 & 1.000 & & & \\
Profit Efficiency(PE) & 0.193 & -0.058 & 1.000 & & \\
Cost Efficiency (CE) & 0.004 & -0.017 & -0.081 & 1.000 & 1.000 \\
Operating Efficiency (OE) & 0.107 & -0.069 & 0.506 & -0.035 & \\
\hline
\end{tabular}

In this study, four models are estimated through fixed effect regression method to determine the effect of corporate governance in the efficiency of banks by considering bank size, macroeconomic, banking structure and economic freedom as a control variable. Table 6 , model 1 showing the relationship among management efficiency, corporate 
governance and control variables and the statistical result shows a significant negative impact of corporate governance on management efficiency. R-squared is 0.81 while Adjusted R-Squared is 0.78 and F-statistic 30.68. It means management efficiency due to corporate governance coefficients shows a negative relationship. The value of bank size is $-1.54(-2.28)^{* * *}$, macroeconomic conditions is $-0.12(-3.04)^{* * *}$, banking structure $-0.15(-$ 0.57 ), and economic freedom is 0.80 (0.65) with management efficiency. It means null hypotheses rejected. Management efficiency measured through Assets Ratio (Average total assets divided by Total revenue has a negative relationship with the corporate governance of banks. This is also in line with corporate governance where it is generally perceived that corporate governance usually hurts management efficiency in the current period. Corporate governance always benefits banks in the long term instead of short term. The result of the second model shows the positive relationship between profit efficiency and corporate governance variable. It means profit efficiency due to corporate governance shows a positive relationship with the value of $0.73(1.77){ }^{* *}$. Also, indicate that one unit change in profit efficiency due to corporate governance (board independence, board size, chairman CEO duality, manager ownership internal control and audit committee) can bring 0.73 unit change in profit efficiency. This is also in line with literature and the basic argument of corporate governance that better corporate governance banks have better profits. The value of bank size is 1.60 (1.23), macroeconomic conditions are $-0.11(-1.36)$, banking structure $1.03(2.02){ }^{* * *}$ and economic freedom is $2.76(1.17)$ with profit efficiency. R-squared is 0.82 , F-statistic 33.18 and this means null hypotheses accepted. It means null hypotheses rejected. There is a significant positive relationship between profit efficiency due to corporate governance.

Model 3 shows the relationship among cost efficiency, corporate governance, and other control variables. The statistical result shows the significant relationship between these two variables as corporate governance is $0.18(1.98){ }^{* * *}$. It means null hypotheses rejected. The value of bank size is $-0.02(-1.42)$, macroeconomic conditions is $-0.02(-$ 1.42), banking structure $0.53(4.70){ }^{* * *}$ and economic freedom is $-1.37(-2.62){ }^{* * *}$ with operating efficiency is $-0.01(-194)^{* * *}, 0.10(2.33)^{* * *}$ and $0.02(0.09)$. The results explicate that corporate governance has a significant influence on cost efficiency and statistically Rsquared is 0.32 , F-statistic 3.34in the case of cost efficiency. Model 4 shows the relationship among operating efficiency, corporate governance, and other control variables. The statistical result shows between these two variables as corporate governance is 0.05 (1.35). Corporate governance has an insignificant impact on the bank's efficiency. Statistically, R-squared is 0.38 , F-statistic 3.34 . It means null hypotheses accepted. Statistically, R-squared is 0.32 , F-statistic 4.41 . The value of bank size, macroeconomic conditions, banking structure and economic freedom with operating efficiency is 0.02 (0.19), $-0.01(-194)^{* * *}, 0.10(2.33)^{* * *}$ and $0.02(0.09)$ respectively. It can be concluded that corporate governance has no impact on the bank's operating efficiency. 
Table 6: Results of Panel Regression (Fixed Effect Model)

\begin{tabular}{|c|c|c|c|c|}
\hline Variable & $\begin{array}{l}\text { Management } \\
\text { Efficiency }\end{array}$ & Profit Efficiency & Cost Efficiency & Operating Efficiency \\
\hline Indicator & $\begin{array}{l}\text { Assets } \\
\text { (Average total } \\
\text { divided by } \\
\text { revenue }\end{array}$ & $\begin{array}{l}\text { Ratio } \\
\text { assets } \\
\text { Total }\end{array}$ & $\begin{array}{l}\text { Exp to Asset ratic } \\
\text { \{(Admin expense } \\
\text { Noninterest } \\
\text { Expense/Total } \\
\text { Assets)] }\end{array}$ & $\begin{array}{l}\text { +Spread ratio (Bank } \\
\text { size/admin } \\
\text { expense)*100 }\end{array}$ \\
\hline Constant & $21.47(2.57)^{\star * *}$ & $-8.70(-0.51)$ & $-8.56(-2.40)^{* * *}$ & $-0.58(-0.44)$ \\
\hline Corporate Governance & $-0.49(-2.24)^{* * *}$ & $0.73(1.77)^{* *}$ & $0.18(1.98)^{* * *}$ & $0.05(1.35)$ \\
\hline Bank Size & $-1.54(-2.28)^{\star \star *}$ & $1.60(1.23)$ & $0.44(1.52)$ & $0.02(0.19)$ \\
\hline Macroeconomic Conditions & $-0.12(-3.04)^{\star * *}$ & $-0.11(-1.36)$ & $-0.02(-1.42)$ & $-0.01(-194)^{\star * *}$ \\
\hline Banking Structure & $-0.15(-0.57)$ & $1.03(2.02)^{* * *}$ & $0.53(4.70)^{* * *}$ & $0.10(2.33)^{* * *}$ \\
\hline Economic Freedom & $0.80(0.65)$ & $2.76(1.17)$ & $-1.37(-2.62)^{\star * *}$ & $0.02(0.09)$ \\
\hline R-squared & 0.81 & 0.82 & 0.32 & 0.38 \\
\hline Adjusted R-squared & 0.78 & 0.80 & 0.22 & 0.29 \\
\hline F-statistic & 30.68 & 33.18 & 3.34 & 4.41 \\
\hline Prob (F-statistic) & 0.00 & 0.00 & 0.00 & 0.00 \\
\hline
\end{tabular}

${ }^{*}$ And ${ }^{* * *}$ are denoted with $10 \%$ and $1 \%$ p-value and t-statistics presented in parentheses

\section{Conclusion and Policy Implications}

The study aims are to determine the role of corporate governance in banks efficiency in Pakistan. Moreover, consider dimensions like board size, managerial ownership, the duality of the CEO, board independence, and the independence of the audit committee on bank's efficiency aspect is like cost efficiency, profit efficiency, management efficiency, and operating efficiency. The Corporate governance index is computed with dummy variables to test whether there is any impact of corporate governance on the efficiency of the bank.

Furthermore, in this study uses four control variables bank size, macroeconomic condition, banking structure, and economic freedom by considering that efficiency of banks can attract domestic and foreign investment in shaping up the banking sector positively and stable economic growth in the country. The sample size in this study is 21 banks for the period 2006-2016. Secondary data is extracted from financial reports of 21 banks, World Bank, WDI, Financial Structure and development, and World Governance Indicators. Panel data is used to find the nature of the relationship that exists between the dependent and the independent variables of efficiency and corporate governance. From Hausman, test results applied the fixed effect model as an estimation technique through E- views. Model 1 shows the negative relationship between management efficiency and corporate governance and the statistical result shows a significant relationship. The Model 2 results indicate a positive correlation between profit efficiency (earning per share) and corporate governance; it means one positive unit change in corporate governance would lead to enhance earnings per share changes due to corporate governance and null hypotheses accepted. The results of model 3 show that corporate governance has a significant influence on cost efficiency. The results of model 4 show that there is no impact on the corporate governance of banks on operating efficiency.

The bank's profitability and efficiency can lead to bear debt burden, also benefit the wellbeing of depositors, shaping the real economy through economic growth and 
routine people. Banks must create purposeful and stronger boards, improve the timing, accuracy, scope of financial reporting and concentrate on the interests and rights of minority shareholders. Robust accounting standards, proper security, corporate laws, efficient judicial systems, and effective regulators together can ensure the foundations of good Corporate governance and maximum efficiency level. Independence of audit committee can play an active role in the minimization of default cases like KASB bank and recent scams of four ads/ money laundering. Moreover, we suggest that Pakistani banks improved a lot after the banking reforms passed in the 1990s, 2000s and during the recent decade but there is still a need for second-generation banking reforms.

\section{References}

Abreu, E.S.D, Kimura, H., Sobreiro, V. A (2019)., What is going on with studies on banking efficiency?, Research in International Business and Finance, Volume 47, Pages 195-219, https://doi.org/10.1016/i.ribaf.2018.07.010.

Adams, R. B., Mehran, H. (2005).Corporate performance, board structure and its determinants in the banking industry. Working paper, Federal Reserve Bank of New York.

Adams, R.B. A., Ferreira, D. (2009).Women in the boardroom and their impact on governance and performance. Journal of Financial Economics, 94(2): p.p. 291-309.

Akhtar, M. A. (2010). X-Efficiency Analysis of Commercial Banks in Pakistan: A Preliminary Investigation. The Pakistan Development Review, Vol. 41(4), pp. 567-580.

Andres P.D., Vallelado, E. (2008). Corporate governance in banking: The role of the board of directors, Journal of Banking \& Finance, 32 (12): p.p. 2570-2580. www.elsevier.com/locate/jbf

Ataullah, A., Cockerill, T., Le, H. (2004). Financial Liberalization and Bank Efficiency: A Comparative Analysis of India and Pakistan, Applied Economics, Vol. 36(17), pp. 1915-1924.

Bakhit, W., Bakhit, S. (2014). Banks' Stability: The effect of Monetary Policies in light of the Global Financial Crisis. International Journal of Finance \& Banking Studies, 3(2): 2147-4486.

Basel Committee on Banking Supervision (BCBS), Enhancing Corporate Governance for Banking Organizations. Switzerland: Bank for International Settlements.

Bebchuk, L.A., Weisbach, M.S. (2010). The state of corporate governance research. The Review of Financial Studies, 23(3): p.p. 939-961.

Burki, A. A., Ahmad, S. (2010). Bank governance changes in Pakistan: Is there a performance effect? Journal of Economics and Business, 62(2): pp. 129-146

Burki, A. A., Ahmad, S. (2011). The Impact of Bank Governance on Bank Performance in Pakistan, The Lahore Journal of Economics, 16: pp. 271-300.

Burki, A. A., Niazi, G. S. K. (2010). Impact of financial reforms on the efficiency of state-owned, private and foreign banks in Pakistan, Applied Economics, Vol. 42: pp. 3147-3160.

Collins, H. (2011). Creative Research: The Theory and Practice of Research for the Creative Industries, AVA Publications.

De Haan, J., Vlahu, R. (2015). Corporate governance of banks: a survey, Journal of Economic Surveys. doi:10.1111/joes.12101

Deb, R., (2013)., Corporate Governance Practices in Indian Banks, Journal of Business Management \& Social Sciences Research, (JBM\&SSR), Volume 2, No.5,

Eilon, S., (1980). The non-executive director. The International Journal of Management, 8: 399-407.

Fanta, B. A., Kemal, S. K., Waka, K. Y. (2013). Corporate governance and the impact on bank performance. Journal of Finance and Accounting, vol. 1, No. 1, pp.19-26.doi: 10.11648/j.jfa.20130101.12 
Forbes, Milliken, F. (1999). Cognition and corporate governance: Understanding boards of directors as strategic decision-making groups. Academy of Management Review, 24: 489-505.

Güneş N. M. Atılgan, S. (2016)., Comparison of the Effectiveness of Audit Committees in the UK and Turkish Banks, International Journal of Financial Research, Vol. 7, No. 2; 2016

Hayat, S. J. (2011). Efficiency Analysis of Commercial Banks in Pakistan- A Nonparametric Approach. Lahore School of Economics Student Thesis

Javid, Y. A., Iqbal, R. (2010). Corporate Governance in Pakistan: Corporate Valuation, Ownership, and Financing. PIDE Working Papers: 57

Jegede, C. A., Akinlabi, B. H., Soyebo, Y.A. (2013). Corporate governance efficiency and bank performance in Nigeria. World Journal of Social Sciences, Vol. 3(1), pp. $178-192$

Kartal, M. T., İbiş, C Çatıkkaş, O, (2018)., Adequacy of audit committees: A study of deposit banks in Turkey, Borsa Istanbul Review, Volume 18, Issue 2,https://doi.org/10.1016/j.bir.2018.01.002.

Khalid, U. (2006). The Effect of Privatization and Liberalization on Banking Sector Performance in Pakistan", SBP Research Bulletin, Vol. 2(2): pp. 403-425.

Khan, M. Z. (1998).Transforming banking in Pakistan. The study commissioned by ADB for RETA 5770: Study of Financial Markets in Selected Member Countries, 28 August.

Khrawish, H. A. (2011). Determinants of commercial banks performance: evidence from Jordan. International Research Journal of Finance and Economics, 81, 148-159.

Klein, A. (2002). Audit Committee, Board of Director Characteristics, and Earnings Management. Journal of Accounting \& Economics, Vol. 33: pp. 375-400.

Kujansivu, Lönnqvist (2006). The Value and Efficiency of Intellectual Capital in Finnish Companies. Retrieved from www.tut.fi/units/tuta/tita/tip/Kujansivu_Lonnqvist.pdf

La Porta, R., Shleifer, A. Vishny, W. R. (1999). Investor Protection and Corporate Governance. SSRN: $h$ ttp://ssrn.com/abstract $=183908$

Laeven, L., \& Levine, R. (2009).Corporate governance, regulation, and bank risk-taking. Journal of Financial Economics, 93(2): 259-275.

Lassoued, N., L. H. Sassi, H, Attia, M. B. R. (2016). The Impact of State and Foreign Ownership on Banking Risk: Evidence from the MENA Countries. Research in International Business and Finance, 167-178.

Levine, R. (2004). The Corporate Governance of Banks: A Concise Discussion of Concepts and Issues, World Bank Policy Research Paper WPS3404.

Lipton, M,. Lorsch, JW., (1992). A modest proposal for improved corporate governance. A business lawyer, vol. 48(1): p. 59- 77.

Miko, N., U., Kamardin, H., (2016). Can Governance Independence Determine Bank Efficiency?: Evidence from the Nigerian Banking Industry. International Business Management, 10: 24832489. DOI: $10.3923 / \mathrm{ibm} .2016 .2483 .2489$

Minton, B.A., Taillard, J.P.A., Williamson, R. (2010). Board composition, risk-taking, and value: Evidence from financial firms. https://www.eurofidai.org/Taillard_2010.pdf.

Mirzaei, A. \& Moore, T. (2019)., Real Effect of Bank Efficiency: Evidence from Disaggregated Manufacturing Sectors, Economica, Volume86, Issue341, Pages 87-115

Muhammad, N. M. N. Ismail M. K .A. (2009). Intellectual capital Efficiency and Firm's Performance: Study on Malaysian Financial Sectors. International Journal of Economics and Finance, 1(2): 206-212.

Nazir, M. S., Alam, A. (2010). The Impact of Financial Restructuring on the Performance of Pakistani Banks: A DEA Approach. COMSATS Institute of Information Technology Paper.

Njanike, K., Mutengeznwa, M., Gombarume, F. B. (2011). International controls in ensuring good corporate governance in financial institutions. Annals of the University of Petroşani, Economics, Vol: 11(1): pp: 187-196. 


\section{Studies in Business and Economics no. 15(1)/2020}

Novickyte', L. Droždz, J., (2018). Measuring the Efficiency in the Lithuanian Banking Sector: The DEA Application, International Journal of Financial Studies, 6, 37; doi:10.3390/ijfs6020037,

Partovi, E. Matousek, R., (2019)., Bank efficiency and non-performing loans: Evidence from Turkey, Research in International Business and Finance, Volume 48, Pages 287-309, https://doi.org/10.1016/j.ribaf.2018.12.011,

Pathan, S. (2009). Strong Boards, CEO Power, and Bank Risk-taking. Journal of Banking and Finance, Vol. 33: pp. 1,340-50.

Patti, E. B., Hardy, D. C. (2005). Financial sector liberalization, bank privatization, and efficiency: Evidence from Pakistan. Journal of Banking and Finance, Vol. 29: $\quad$ 2381-2406.

Pi, L., Timme, S.G., (1993). Corporate Control in Commercial Banks, Journal of Banking and Finance, Vol. 17 (2-3): p. 515-30.

Pulic, A. (2000a).VAICTM - an Accounting Tool for IC Management. International Journal Technology Management, 20(5/6/7/8):702-714.

Qayyum, A., Ahmad, M. (2006). Efficiency and Sustainability of Micro Finance in South Asia, South Asian Network of Economic Research Institutes (SANEI)

Qayyum, A., Khan S. (2007). X-Efficiency, Scale Economies, Technological Progress, and Competition: A Case of Banking Sector in Pakistan. Pakistan Institute of Development Economics, Islamabad, Pakistan, Working Paper No. 23.

Rehman, R., Mangla, L.U. (2010). Corporate Governance and Performance of Financial Institutions in Pakistan: A Comparison between Conventional and Islamic Banks in Pakistan. The Pakistan Development Review, pp. 461-475.

Shaari, J. A. N., Khalique. M. Isa, A. H. B. M. (2011). Ranking of Public and Domestic Private Sector Commercial Banks in Pakistan from the Intellectual Capital Performance. KASBIT Business Journal, p. 4:61-68.

Tandelilin, E., Kaaro, H., Mahadwartha, A. P., Supriyatna. (2007). Corporate Governance, Risk Management, and Bank Performance: Does Type of Ownership Matter? Final Report of an EADN Individual Research Grant Project, Working paper: 34

Vafeas, N. (2005). Audit Committees, Boards, and the Quality of Reported Earnings. Contemporary Accounting Research, Vol. 22: pp. 1,093-122.

Zheng, C., Moudud-UI-H.S, Rahmanc, M. M. Ashraf, N. B. (2017). Does the ownership structure matter for banks' capital regulation and risk-taking behavior? Empirical evidence from a developing country, Research in International Business and Finance, 404-421.

Zhu, Wenyu \& Yang, J. (2016). State ownership, cross-border acquisition, and risk-taking: Evidence from China's banking industry. Journal of Banking \& Finance, 133-153. 
APPENDIX. 1

\section{List Of Banks}

\begin{tabular}{|llll}
\hline Sr. No & Bank Name & Sr. No & Bank Name \\
\hline $\mathbf{1}$ & Allied Bank Limited & 12 & KASB bank \\
\hline $\mathbf{2}$ & Albaraka Bank Limited & 13 & Muslim commercial bank (MCB) \\
\hline $\mathbf{3}$ & Askari Bank Limited & 14 & Meezan Bank \\
\hline $\mathbf{4}$ & Bank Al-Habib & 15 & National bank of Pakistan (NBP) \\
\hline $\mathbf{5}$ & Bank Alfalah Limited & 16 & NIB \\
\hline $\mathbf{6}$ & Bank Islami & 17 & $\begin{array}{l}\text { Silk Bank Limited (Saudi Pak Commercial } \\
\text { Bank Limited) }\end{array}$ \\
\hline $\mathbf{7}$ & Bank of Khyber & 18 & Soneri Bank Limited \\
\hline $\mathbf{8}$ & Bank of Punjab & 19 & Standard Chartered \\
\hline $\mathbf{9}$ & Faysal Bank Limited & 20 & Summit Bank \\
\hline $\mathbf{1 0}$ & Habib Bank Limited & 21 & United Bank Limited (UBL) \\
\hline $\mathbf{1 1}$ & JS bank & & \\
\hline
\end{tabular}

